Article

\title{
Synthesis of cis- and trans-3-Aminocyclohexanols by Reduction of $\beta$-Enaminoketones
}

Iris Montoya Balbás, Blanca Eda Domínguez Mendoza, Mario Fernández-Zertuche, Mario Ordoñez and Irma Linzaga-Elizalde *

Centro de Investigaciones Químicas, Universidad Autónoma del Estado de Morelos, Av. Universidad 1001, Cuernavaca, Mor., CP 62209, Mexico

* Author to whom correspondence should be addressed; E-Mail: linzaga@uaem.mx; Tel.: +52-77-7329-7997.

Received: 25 October 2011; in revised form: 21 December 2011 / Accepted: 22 December 2011 / Published: 27 December 2011

Abstract: We describe a protocol developed for the preparation of $\beta$-enaminoketones derived from 1,3-cyclohexanediones, and their subsequent reduction by sodium in THF-isopropyl alcohol to afford cis- and trans-3-aminocyclohexanols.

Keywords: 1,3-amino alcohols; 3-aminocyclohexanols; $\beta$-enaminoketones; reduction of $\beta$-enaminoketones

\section{Introduction}

Amino alcohols are of great interest because of their biological and structural importance. For example, acyclic 1,3-amino alcohols are key structural components of numerous natural products [1-6], potent drugs [7,8], and components of numerous medicinal compounds such as HIV-protease inhibitors [9], $\mu$-opioid receptor antagonists [10], potent antibiotic negamycin [11-13], serotonin reuptake inhibitor, and antidepressants [14]. Additionally, 1,3-amino alcohols are useful chiral building blocks in asymmetric synthesis functioning as chiral ligands and auxiliaries [15-23]. Despite their prevalence and the importance of acyclic 1,3-amino alcohols [24-27], there are only a few synthetic methods reported in the literature to access to this important class of compounds [28-31], and even fewer reports exist regarding the synthesis of 1,3-aminocyclohexanols [32-34]. We wish to report 
herein our results on the reduction of $\beta$-enaminoketones, leading to the synthesis of both cis- and trans3-aminocyclohexanols.

\section{Results and Discussion}

Our method starts with the condensation reaction of 4,4-dimethyl-1,3-cyclohexanedione with either benzylamine or $(S)$ - $\alpha$-methylbenzylamine in toluene at reflux, conditions that lead to the $\beta$-enaminoketones 1 and $\mathbf{2}$ in 85 and 87\% yield, respectively (Scheme 1) [35,36]. Both products were fully characterized by NMR spectroscopy and the stereochemistry was corroborated by their X-ray crystal structure [37] (Figure 1).

Scheme 1. Preparation of $\beta$-enaminoketones 1 and 2.<smiles>CC1(C)CC(=O)CC(=O)C1</smiles><smiles>[R]C(N)Pc1ccccc1</smiles><smiles>[R]C(NC1=CC(=O)CC(C)(C)C1)c1ccccc1</smiles>

$$
\begin{aligned}
& 1 ; R=H, 85 \% \\
& 2 ; R=M e, 87 \%
\end{aligned}
$$

Figure 1. X-Ray structure of $\beta$-enaminoketone 2 .

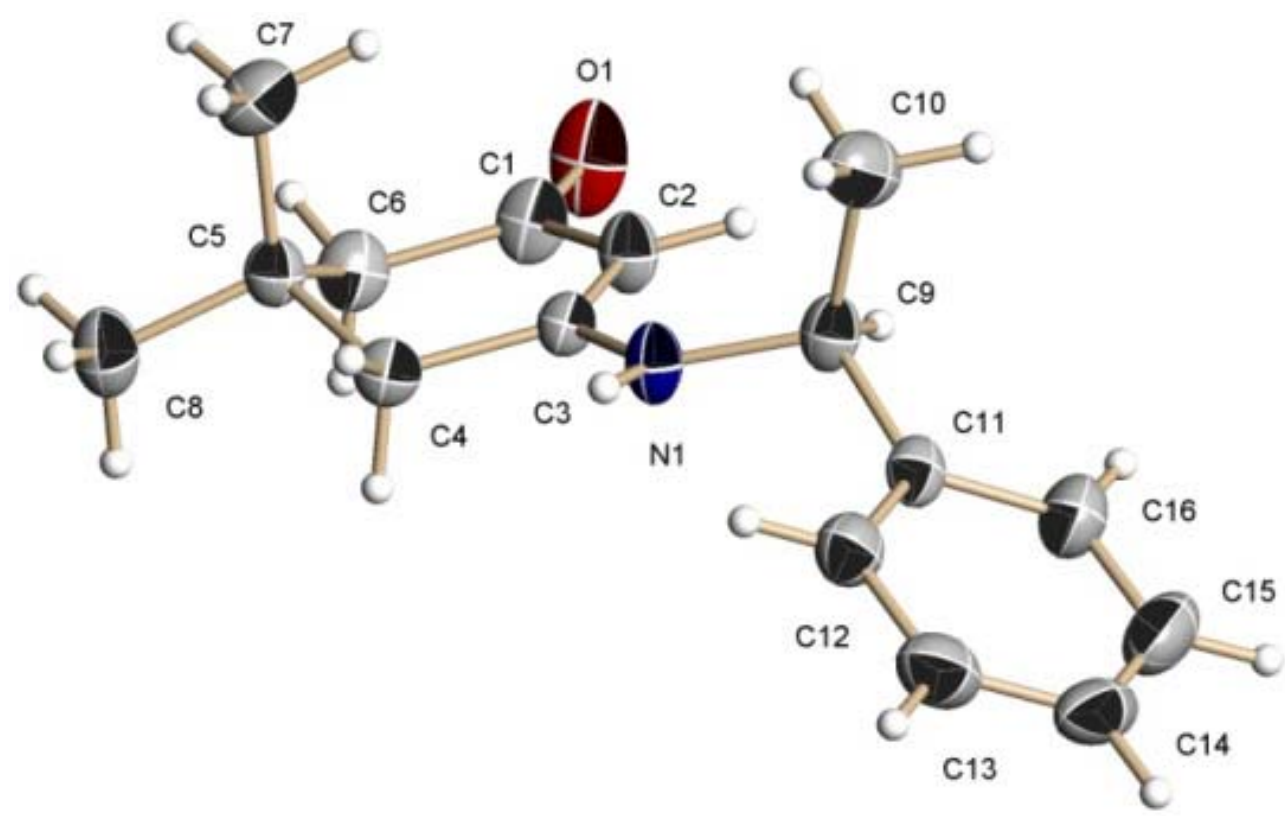

In a subsequent step, the reduction of $\beta$-enaminoketones $\mathbf{1}$ and $\mathbf{2}$ was carried out following a procedure described in the literature [38-45]. Thus, the reaction of $\mathbf{1}$ and $\mathbf{2}$ with sodium in a mixture of THF/isopropyl alcohol at room temperature afforded the corresponding diasteromeric mixture of amino alcohols 3 and $\mathbf{4}$ in 77 and 75\% yield, respectively (Scheme 2). 
Scheme 2. Reduction of $\beta$-enaminoketones 1 and 2.

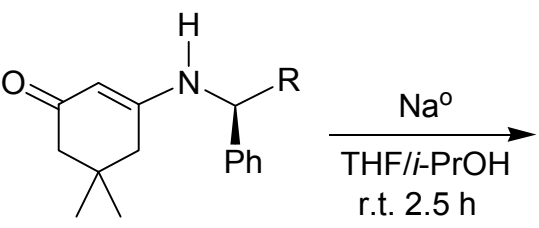

$1 ; \mathrm{R}=\mathrm{H}$

2; $R=M e$<smiles>[R]C(NC1CC(O)CC(C)(C)C1)Pc1ccccc1</smiles>

3; $\mathrm{R}=\mathrm{H}, 77 \%$

4; $\mathrm{R}=\mathrm{Me}, 75 \%$

A percolation of the reaction mixture followed by GC-MS analysis using a cyclosil-B chiral column revealed the presence of four major stereoisomers in identical ratio for compound $\mathbf{3}$ and two stereoisomers for compound 4 (cis and trans in 89:11 ratio). The diastereoisomeric separation of 3 was not attempted; however, column chromatography separation of $\mathbf{4}$ afforded the cis-4 and trans-4 in 69 and $6 \%$ yield, respectively.

Considering the X-ray structure of $\beta$-enaminoketone 2, a reasonable explanation of the high cis:trans diastereoselectivity in its reduction step can be explained assuming that the allyl anion A obtained by successive electron-transfers from the sodium to the conjugate system of enaminone, is the more stable conformation, because it avoids the interaction of $\mathrm{C}-10$ or $\mathrm{Ph}$ with $\mathrm{C} 2-\mathrm{H}$ observed in conformation B. Thus, protonation with isopropyl alcohol of the corresponding allyl anion in the conformation A takes place selectively from the bottom-face, since the top-face is hindered by the methyl group (Figure 2).

Figure 2. Plausible explanation of the diastereoselectivity in the reduction of 2.<smiles>C[C@H](NC1=CC(=O)CC(C)(C)C1)c1ccccc1</smiles>

2<smiles>CC(C)OCCC1(C)CC(C)(C)CC(O)C1N[C@H](C)c1ccccc1</smiles>

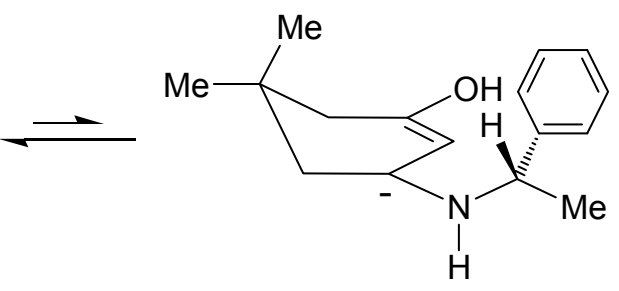

B

Additionally, structural elucidation for cis-4 and trans-4 was accomplished through ${ }^{1} \mathrm{H}-$ and ${ }^{13} \mathrm{C}-\mathrm{NMR}$, as well as 2D NMR spectra like COSY, HSQC and NOESY. Spectra data for $c i s-4$ and trans $\mathbf{- 4}$ are shown in Table 1 . In the ${ }^{1} \mathrm{H}-\mathrm{NMR}$ spectra of compound cis-4, protons $\mathrm{H}_{1}$ and $\mathrm{H}_{3}$ exhibit a triplet of triplets multiplicity, with coupling constants of $11.2,4.8 \mathrm{~Hz}$ and 11.6, 4.0 Hz, respectively. Analysis of these coupling constants confirms the axial disposition of both protons establishing then an equatorial distribution of the $\mathrm{OH}$ and NHR groups. Additionally, proton $\mathrm{H}_{2 \mathrm{~b}}$ presents a quadruple signal $(J=11.6 \mathrm{~Hz})$ which determines its axial position whereas $\mathrm{H}_{2 \mathrm{a}}$ is occupies an equatorial position. The multiplicity of $\mathrm{H}_{4 \mathrm{a}}(\mathrm{ddt})$ shows three couplings constants ${ }^{2} J=12.8 \mathrm{~Hz},{ }^{3} J_{\text {ec/ax }}=3.6 \mathrm{~Hz}$ and ${ }^{4} J_{H 4 a / H 6 a}=2 \mathrm{~Hz}$, this scalar coupling establishes that $\mathrm{H}_{1}$ and $\mathrm{H}_{3}$ occupy axial positions (Figure 3 ). 
Table 1. ${ }^{1} \mathrm{H}$ And ${ }^{13} \mathrm{C}-\mathrm{NMR}$ chemical shifts for the compounds cis-4 and trans-4.

\begin{tabular}{|c|c|c|c|c|c|}
\hline \multicolumn{5}{|c}{ cis-4 } & \multicolumn{2}{c|}{ trans $-\mathbf{4}$} \\
\hline Proton & ${ }^{1} \mathbf{H} \boldsymbol{\delta}(\mathbf{p p m}), \boldsymbol{J}(\mathbf{H z})$ & Carbon & ${ }^{13} \mathbf{C} \boldsymbol{\delta}(\mathbf{p p m})$ & ${ }^{\mathbf{1}} \mathbf{H} \boldsymbol{\delta}(\mathbf{p p m}), \boldsymbol{J}(\mathbf{H z})$ & ${ }^{13} \mathbf{C} \boldsymbol{\delta}(\mathbf{p p m})$ \\
\hline $\mathrm{H}_{1}$ & $3.65(\mathrm{tt}, J=11.2,4.8,1 \mathrm{H})$ & $\mathrm{C}_{1}$ & 66.8 & $3.64(\mathrm{tt}, J=10.8,4.4,1 \mathrm{H})$ & 67.1 \\
\hline $\mathrm{H}_{2 a}$ & $2.13\left(\mathrm{~m}, J_{\text {gem }}=11.6,1 \mathrm{H}\right)$ & $\mathrm{C}_{2}$ & 43.3 & $2.35(\mathrm{dddd}, J=11.6,5.6,4.2,1 \mathrm{H})$ & 42.6 \\
$\mathrm{H}_{2 b}$ & $1.07(\mathrm{q}, J=11.6,1 \mathrm{H})$ & & & $0.94(\mathrm{bq}, J=10.2,1 \mathrm{H})$ & \\
\hline $\mathrm{H}_{3}$ & $2.53(\mathrm{tt}, J=11.6,4.0,1 \mathrm{H})$ & $\mathrm{C}_{3}$ & 49.5 & $2.59(\mathrm{tt}, J=11.6,4.0,1 \mathrm{H})$ & 49.3 \\
\hline $\mathrm{H}_{4 a}$ & $1.70(\mathrm{ddt}, J=12.8,3.6,2.0,1 \mathrm{H})$ & $\mathrm{C}_{4}$ & 44.7 & $1.50(\mathrm{~m}, 1 \mathrm{H})$ & 46.5 \\
$\mathrm{H}_{4 b}$ & $0.97(\mathrm{t}, J=12.0,1 \mathrm{H})$ & & & $0.99(\mathrm{t}, J=12.0,1 \mathrm{H})$ & \\
\hline $\mathrm{H}_{5}$ & - & $\mathrm{C}_{5}$ & 31.8 & -1.7 & 31.7 \\
\hline $\mathrm{H}_{6 a}$ & $1.63(\mathrm{ddt}, J=12.4,4.0,2.0,1 \mathrm{H})$ & $\mathrm{C}_{6}$ & 48.1 & $1.63(\mathrm{ddt}, J=12.4,4.0,2.0,1 \mathrm{H})$ & 48.4 \\
$\mathrm{H}_{6 b}$ & $0.97(\mathrm{t}, J=11.8,1 \mathrm{H})$ & & & $1.04(\mathrm{bq}, J=12.0,1 \mathrm{H})$ & \\
\hline $\mathrm{H}_{7}$ & $0.97(\mathrm{~s}, 3 \mathrm{H})$ & $\mathrm{C}_{7}$ & 33.3 & $0.93(\mathrm{~s}, 3 \mathrm{H})$ & 33.2 \\
\hline $\mathrm{H}_{8}$ & $0.70(\mathrm{~s}, 3 \mathrm{H})$ & $\mathrm{C}_{8}$ & 26.0 & $0.75(\mathrm{~s}, 3 \mathrm{H})$ & 26.2 \\
\hline $\mathrm{H}_{9}$ & $4.00(\mathrm{q}, J=6.4,1 \mathrm{H})$ & $\mathrm{C}_{9}$ & 55.1 & $4.03(\mathrm{q}, J=6.8,1 \mathrm{H})$ & 54.8 \\
\hline $\mathrm{H}_{10}$ & $1.42(\mathrm{~d}, J=6.4,3 \mathrm{H})$ & $\mathrm{C}_{10}$ & 24.3 & $1.40(\mathrm{~d}, J=6.8,3 \mathrm{H})$ & 24.9 \\
\hline $\mathrm{C}_{6} \mathrm{H}_{5}$ & $7.30-7.38(\mathrm{~m}, 5 \mathrm{H})$ & $\mathrm{C}_{i p s o}$ & 144.3, & $7.32-7.35(\mathrm{~m}, 5 \mathrm{H})$ & 145.4, \\
& & $\mathrm{C}_{\text {meta }}$ & 128.7, & & 128.7, \\
& & $\mathrm{C}_{\text {ortho }}$ & 127.3, & & $127.1,126.7$ \\
& & $\mathrm{C}_{\text {para }}$ & 126.8 & & - \\
\hline $\mathrm{NH}$, & $2.37(\mathrm{bs}, 2 \mathrm{H})$ & & -- & $2.01(\mathrm{bs}, 2 \mathrm{H})$ & \\
\hline $\mathrm{OH}$ & & & & & \\
\hline
\end{tabular}

Figure 3. Conformation of the compound cis-4.<smiles>CC(NC1(C)C2(C)CC3C(C)(C2(C)C)C(C)(C)C31C)c1ccccc1</smiles>

The coupling pattern shown by compound cis-4 establishes a syn diequatorial distribution of the $\mathrm{OH}$ and NHR groups. A NOESY experiment (Figure 4) carried out on this compound, shows that $\mathrm{H}_{1}$ interacts with $\mathrm{H}_{3}$ and both protons are close to the equatorial $\mathrm{H}_{2 \mathrm{a}}$. In addition, $\mathrm{H}_{2 \mathrm{~b}}, \mathrm{H}_{6 \mathrm{~b}}$ and $\mathrm{H}_{4 \mathrm{~b}}$ show dipolar couplings confirming the analysis of the coupling constants described previously.

The ${ }^{1} \mathrm{H}-\mathrm{NMR}$ spectra of the compound trans-4 displays similar data to those observed for the cis-4 stereoisomer, the main difference being the chemical shift for protons $\mathrm{H}_{2 \mathrm{a}}, \mathrm{H}_{2 \mathrm{~b}}$, and $\mathrm{H}_{4 \mathrm{a}}$. On the other hand, its ${ }^{13} \mathrm{C}$-NMR data shows that $\mathrm{C}_{4}$ is shifted downfield by $2.0 \mathrm{ppm}$. This can be attributed to a lesser ring strain around this atom. In addition, the coupling pattern for proton $\mathrm{H}_{2 \mathrm{a}}$ is different due to dihedral angles variations (Figure 5). 
Figure 4. NOESY experiments for $\operatorname{cis}-4\left(\mathrm{CDCl}_{3}, 400 \mathrm{MHz}\right)$.

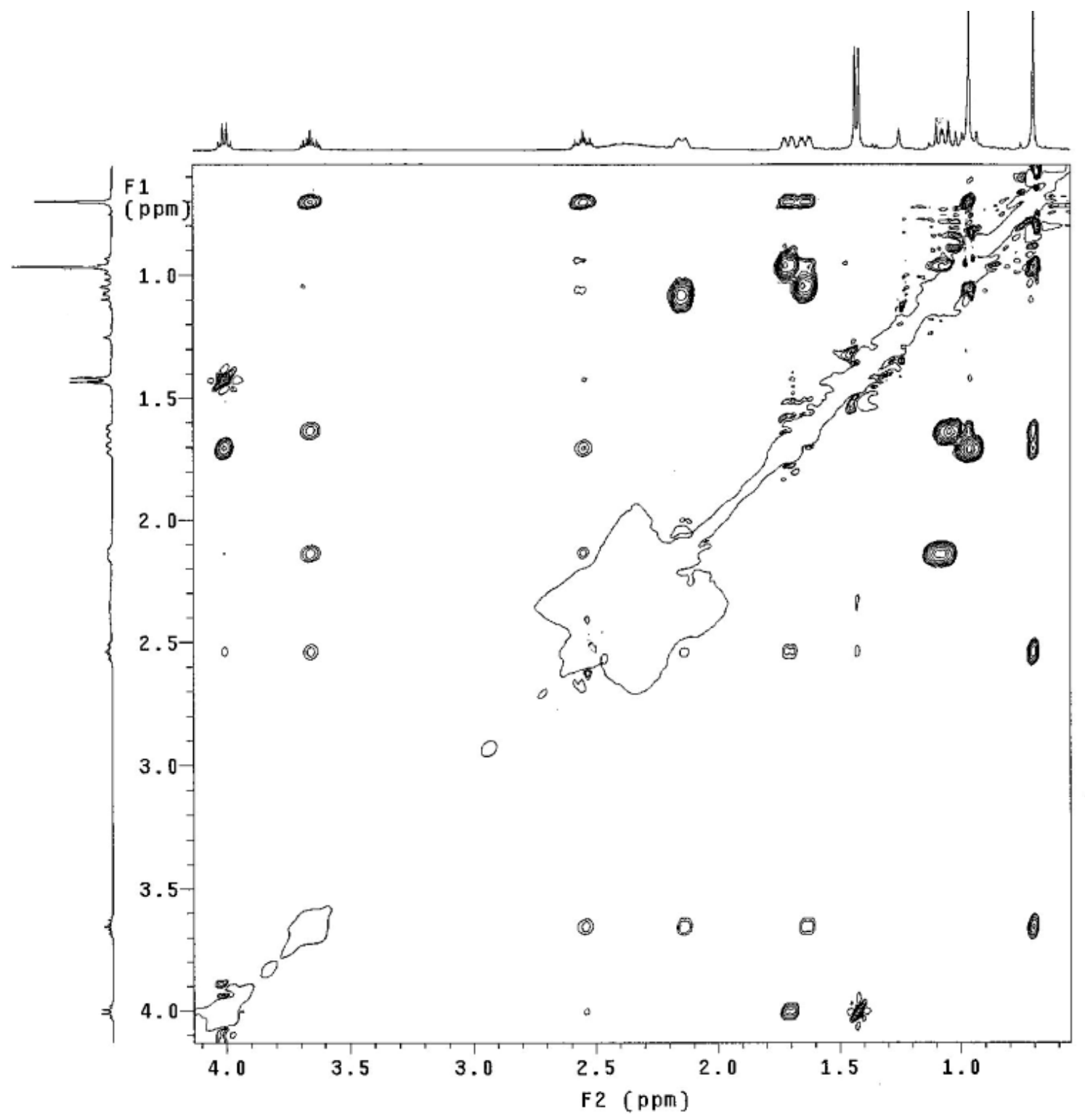

Figure 5. Multiplicity of the protons $\mathrm{H}_{2 e c}$ for compounds cis $\mathbf{- 4}$ and trans-4.
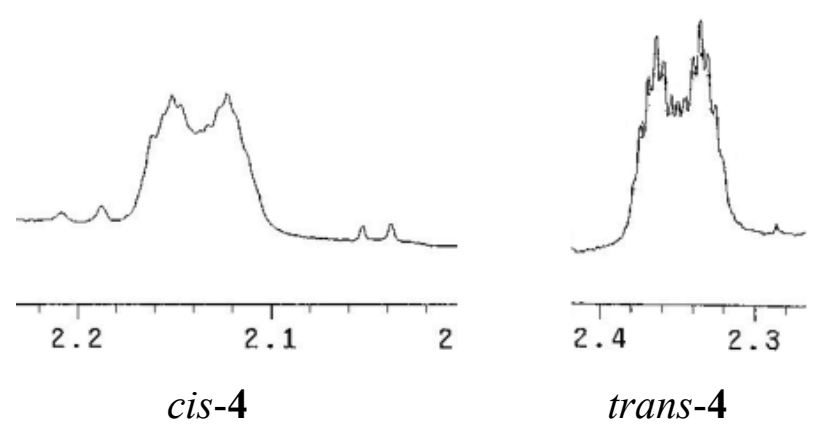

Compound trans $\mathbf{- 4}$ shows a triplet of triplets for the $\mathrm{H}_{1}$ and $\mathrm{H}_{3}$ protons $(J=11.8,4.4 \mathrm{~Hz}$ and $J=11.6,4.0 \mathrm{~Hz}$ respectively), which are similar to those observed for cis-4. However, in the NOESY experiment (Figure 6) these two protons do not interact spatially, suggesting an anti-arrangement of the hydroxyl and amino groups. 
Figure 6. NOESY experiment for compound trans-4 $\left(\mathrm{CDCl}_{3}, 400 \mathrm{MHz}\right)$.

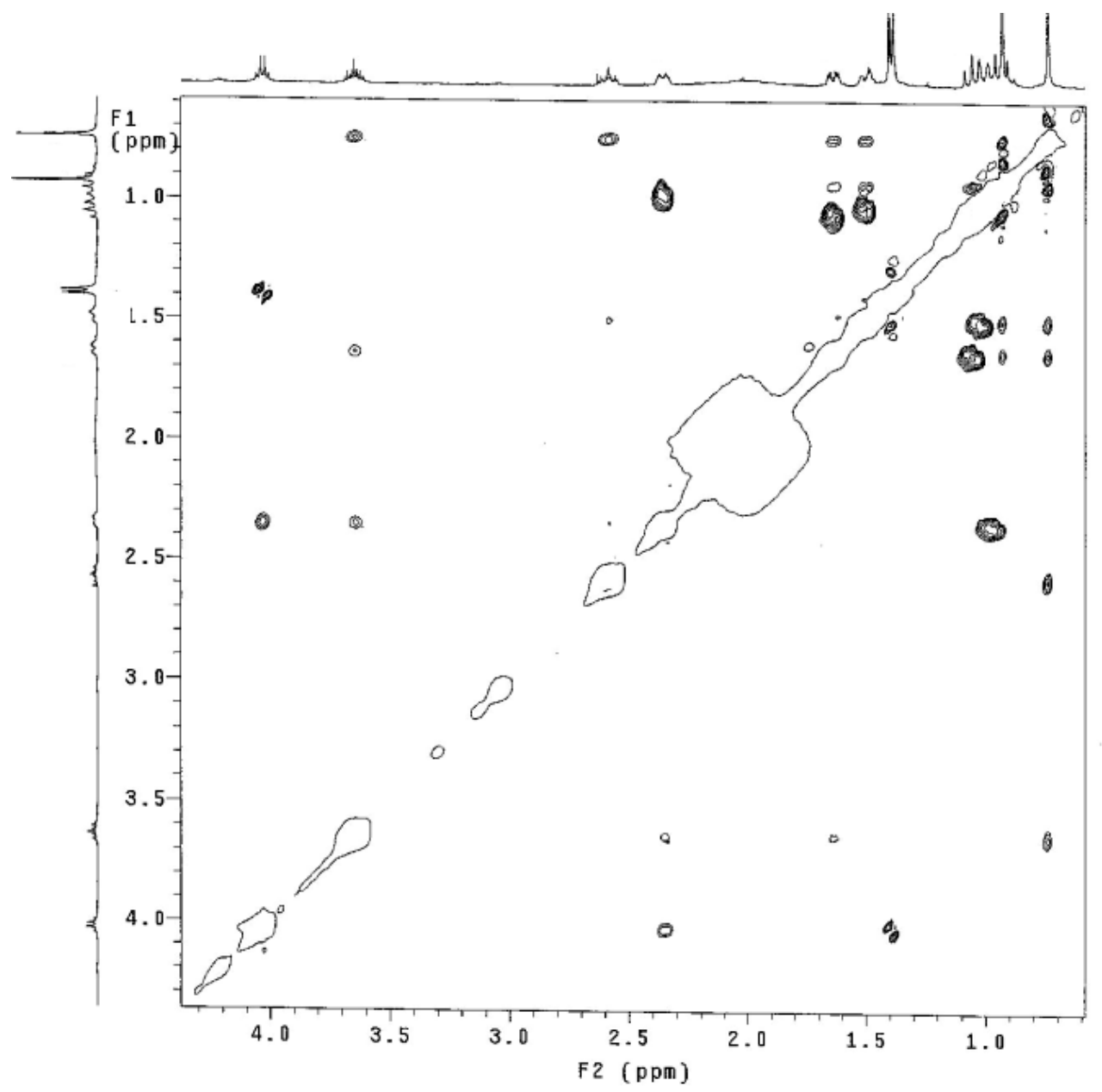

In order to establish the relative configuration at $\mathrm{C}-1$ and $\mathrm{C}-3$ of compound 4 , we also carried out a NOESY experiment (Figure 7). If a chair conformation is considered for compound trans-4 (A), the fact that $\mathrm{H}_{3}$ has a dihedral angle below $60^{\circ}$ with respect to $\mathrm{H}_{2 \mathrm{a}}, \mathrm{H}_{2 \mathrm{~b}}, \mathrm{H}_{4 \mathrm{a}}$ and $\mathrm{H}_{4 \mathrm{~b}}$, would generate coupling constants with magnitude around $\sim 3-5 \mathrm{~Hz}$ according to the Karplus rule, however, this is not observed in the spectrum of this compound.

Figure 7. Proposed conformations for the compound trans-4 in solution.

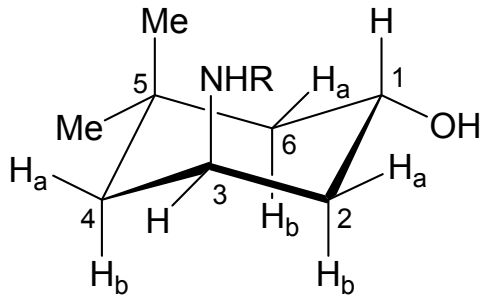

C

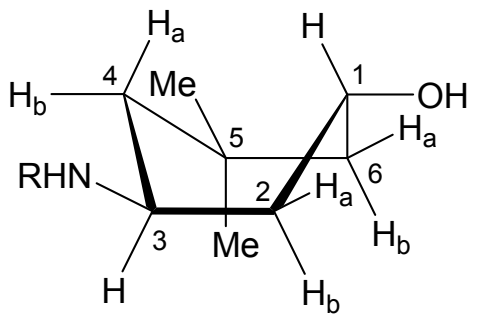

D

These experimental data thus confirm that the compound trans-4 does not adopt a chair conformation as its isomer cis-4 does. Therefore, we carried out an additional NOESY experiment in order to establish the relative configurations at C-1 and C-3, analyzing the coupling constants and spatial interactions of the two possible conformations $\mathbf{C}$ and $\mathbf{D}$ (Table 2). 
Table 2. NOE interactions for $\mathrm{H}_{1}, \mathrm{H}_{3}, \mathrm{H}_{4 \mathrm{eq}}$ and $\mathrm{H}_{6 \mathrm{eq}}$.

\begin{tabular}{|c|c|c|}
\hline Proton & cis-4 & trans-4 \\
\hline 1 & $3,2_{e q}, 4_{e q}, \mathrm{Me}_{\text {upfield }}$ & $2_{e q}, 6_{e q}$ \\
3 & $1,2_{e q}, 4_{e q}, 7 \mathrm{ax}$ & $\mathrm{Me}_{\text {upfield }}, 4_{e q}$ \\
$6_{e q}$ & -- & $6_{a x}, \mathrm{Me}_{\text {downfield }}$ \\
$4_{e q}$ & -- & $\mathrm{Me}-7, \mathrm{Me}-8$ \\
\hline
\end{tabular}

In conformation $\mathbf{D}$, proton $\mathrm{H}_{3}$ shows a dihedral angle larger than $120^{\circ}$ with $\mathrm{H}_{2 \mathrm{a}}$ and $\mathrm{H}_{4 \mathrm{a}}$, this spatial arrangement exhibits coupling constants of $\sim 12.0 \mathrm{~Hz}$, and the coupling with $\mathrm{H}_{2 \mathrm{~b}}$ and $\mathrm{H}_{4 \mathrm{~b}}$ of $4.0 \mathrm{~Hz}$. On the other hand the NOESY experiment shows the spatial proximity of $\mathrm{H}_{4 \mathrm{~b}}$ to both methyl groups at $\mathrm{C}_{5}$, and of proton $\mathrm{H}_{1}$ to both $\mathrm{H}_{2 \mathrm{a}}$ and $\mathrm{H}_{6 \mathrm{a}}$. In addition the fact that proton $\mathrm{H}_{3}$ shows a proximity to $\mathrm{H}_{4 \mathrm{~b}}$, suggests a boat conformation for compound trans -4 . The shielding of $\mathrm{H}_{4 \mathrm{a}}$ is caused by the proximity of the NHR substituent, the torsional effect and the steric hindrance of the boat conformation explains the variation of the chemical shift of $\mathrm{C}_{4}$ in comparison to that of compound cis-4.

\section{Experimental}

Reagents were obtained from commercial suppliers and were used without further purification. Melting points were determined in a Fischer-Johns apparatus and are uncorrected. NMR studies were carried out with a Varian Gemini 200 and Varian Inova 400 instruments using TMS as a standard $\left({ }^{1} \mathrm{H}\right.$, ${ }^{13} \mathrm{C}$ ). Chemical shifts are stated in parts per million. IR spectra have been recorded on a Bruker Vector 22 FT spectrophotometer. The diastereoisomeric composition were determined by GC-MS on the HP 5989A, Cyclosil-B column, $30 \mathrm{~m}, 0.25 \mathrm{~mm}$ (ID), $0.25 \mu \mathrm{m}$ (film), transfer line $220{ }^{\circ} \mathrm{C}$, injection $220^{\circ} \mathrm{C}$, and HRMS in Jeol JMS 700 equipment. X-ray diffraction studies were performed on a BrukerAPEX diffractometer with a CCD area detector at $100 \mathrm{~K}\left(\lambda_{\mathrm{Mo} \mathrm{K \alpha}}=0.71073 \mathrm{~A}\right.$, monochromator: graphite). Specific rotations were measured in a Perkin-Elmer 341 polarimeter at room temperature and $\lambda=589 \mathrm{~nm}$.

\subsection{General Experimental Procedures}

5,5-Dimethyl-3-benzylaminocyclohexen-2-one (1). A solution of 4,4-dimethyl-1,3-cyclohexanedione $(1.0 \mathrm{~g}, 7.13 \mathrm{mmole})$ and benzylamine $(0.86 \mathrm{~mL}, 7.84 \mathrm{mmole})$ was refluxed in toluene $(30 \mathrm{~mL})$ for $3 \mathrm{~h}$, while the water formed was azeotropically removed using a Dean-Stark trap. After this time, the solvent was removed under reduced pressure and the resulting yellow solid was purified by recrystallization $\left(\mathrm{CH}_{2} \mathrm{Cl}_{2}\right.$ /hexane) affording 1 (1.39 g, 85\%), mp $=122-125{ }^{\circ} \mathrm{C}$. IR (film $\mathrm{CH}_{2} \mathrm{Cl}_{2}$, $\mathrm{cm}^{-1}$ ): 3,252, 3,062, 1,800, 1,545. ${ }^{1} \mathrm{H}-\mathrm{NMR}\left(400 \mathrm{MHz}, \mathrm{CDCl}_{3}\right): \delta 1.05$ (s, 6H), $2.14(\mathrm{~s}, 2 \mathrm{H}), 2.25$ (s, 2H), $4.23(\mathrm{~d}, J=10.8 \mathrm{~Hz}, 2 \mathrm{H}), 5.14(\mathrm{~s}, 1 \mathrm{H}), 5.77(\mathrm{bs}, 1 \mathrm{H}), 7.30(\mathrm{~m}, 5 \mathrm{H}) .{ }^{13} \mathrm{C}-\mathrm{NMR}(100 \mathrm{MHz}$, $\left.\mathrm{CDCl}_{3}\right): \delta 28.5(2), 33.0,43.5,47.3,50.2,95.9,127.6(2), 127.9(2), 128.9,136.9,163.5,196.7$. HRMS $\mathrm{CI}^{+}$calcd. for $\mathrm{C}_{15} \mathrm{H}_{20} \mathrm{NO}\left(\mathrm{M}^{+}+1\right): 230.1545$. Found: 230.1538 .

(S)-5,5-Dimethyl-3-( $\alpha$-methylbenzylamino)cyclohexen-2-one (2). A solution of 4,4-dimethyl-1,3cyclohexanedione (1.0 g, $7.13 \mathrm{mmole})$ and $(S)$ - $\alpha$-methylbenzylamine $(1.0 \mathrm{~mL}, 7.84 \mathrm{mmole})$ was refluxed in toluene $(30 \mathrm{~mL})$ during $3.5 \mathrm{~h}$, while the water formed was removed azeotropically using a Dean-Stark trap. After this time, the solvent was removed and the yellow solid obtained was purified by crystallization $\left(\mathrm{CH}_{2} \mathrm{Cl}_{2} /\right.$ hexane $)$ to give compound $2(1.51 \mathrm{~g}, 87 \%), \mathrm{mp}=135-137{ }^{\circ} \mathrm{C}$. 
$[\alpha]_{\mathrm{D}}=-243.26\left(c=1, \mathrm{CHCl}_{3}\right) . \mathrm{IR}\left(\mathrm{KBr}, \mathrm{cm}^{-1}\right): 3,270,3,059,1,750,1,542 \mathrm{~cm}^{-1} .{ }^{1} \mathrm{H}-\mathrm{NMR}(200 \mathrm{MHz}$, $\left.\mathrm{CDCl}_{3}\right): \delta 1.01(\mathrm{~s}, 3 \mathrm{H}), 1.06(\mathrm{~s}, 3 \mathrm{H}), 1.47(\mathrm{~d}, J=6.6 \mathrm{~Hz}, 3 \mathrm{H}), 2.12(\mathrm{~s}, 2 \mathrm{H}), 2.23(\mathrm{~s}, 2 \mathrm{H}), 4.47(\mathrm{q}$, $J=6.6 \mathrm{~Hz}, 1 \mathrm{H}), 4.97(\mathrm{~s}, 1 \mathrm{H}), 5.62(\mathrm{~d}, J=6 \mathrm{~Hz}, 1 \mathrm{H}), 7.26(\mathrm{~m}, 5 \mathrm{H}) .{ }^{13} \mathrm{C}-\mathrm{NMR}\left(50 \mathrm{MHz}, \mathrm{CDCl}_{3}\right): \delta$ 23.6, 28.5(2), 33.1, 43.6, 50.1, 53.0, 97.1, 125.7(2), 127.5, 128.9(2), 142.9, 162.5, 196.5. $\mathrm{HRMS} \mathrm{CI}^{+}$ calcd. for $\mathrm{C}_{16} \mathrm{H}_{22} \mathrm{NO}\left(\mathrm{M}^{+}+1\right)$ : 244.1701, found: 244.1695 .

\subsection{General Procedure for the Reduction of $\beta$-Enaminoketones $\mathbf{1}$ and $\mathbf{2}$}

The $\beta$-enaminoketones $(2.0 \mathrm{mmol})$ were dissolved in a mixture of isopropyl alcohol $(2 \mathrm{~mL})$ and THF $(5 \mathrm{~mL})$. The resulting solution was treated with an excess of small pieces of metallic sodium ( $0.27 \mathrm{~g}, 12.0 \mathrm{~g}$-atoms) and stirred from $0{ }^{\circ} \mathrm{C}$ to room temperature until the reaction was complete (TLC). After removal of the unreacted sodium, the reaction mixture was poured into a saturated aqueous solution of $\mathrm{NH}_{4} \mathrm{Cl}$ and extracted with AcOEt. The organic layers were combined, dried over $\mathrm{Na}_{2} \mathrm{SO}_{4}$ filtered and evaporated under reduced pressure. The resulting materials were submitted to an initial percolation and then were submitted to HPLC-MS analysis. The materials were separated by column chromatography (silica gel, 230-400) eluting with 65:25:10 proportions of hexane/ethyl acetate/isopropyl alcohol or 95:5, $\mathrm{CH}_{2} \mathrm{Cl}_{2} / \mathrm{CH}_{3} \mathrm{OH}$.

5,5-Dimethyl-3-benzylaminocyclohexanols (3a,b). Compound 3a: (97 mg, 48\%). ${ }^{1} \mathrm{H}-\mathrm{NMR}$ (400 MHz, $\left.\mathrm{CDCl}_{3}\right): \delta 0.85(\mathrm{~s}, 3 \mathrm{H}), 0.99(\mathrm{~s}, 3 \mathrm{H}), 1.09(\mathrm{~m}, 3 \mathrm{H}), 1.67(\mathrm{~m}, 2 \mathrm{H}), 2.31\left(\mathrm{~m}, J_{\text {gem }}=11.6 \mathrm{~Hz}, 1 \mathrm{H}\right), 2.79(\mathrm{tt}$, $J=11.6,4 \mathrm{~Hz}, 1 \mathrm{H}), 2.95$ (bs, 2H), 3.75 (tt, $J=11.24 .4 \mathrm{~Hz}, 1 \mathrm{H}), 3.83(\mathrm{~d}, J=12.8 \mathrm{~Hz}, 1 \mathrm{H}), 3.85(\mathrm{~d}$, $J=13.2 \mathrm{~Hz}, 1 \mathrm{H}), 7.3(\mathrm{~m}, 5 \mathrm{H}) .{ }^{13} \mathrm{C}-\mathrm{NMR}\left(50 \mathrm{MHz}, \mathrm{CDCl}_{3}\right): \delta 26.3,31.8,33.3,42.7,45.3,48.2,50.9$, 51.7, 66.6, 127.2, 128.4, 128.6, 139.7. MS, $\mathrm{CI}^{+}\left(\mathrm{M}^{+}+1\right):$ 234, 216, 162, 91. HRMS $\mathrm{CI}^{+}$calcd. for $\mathrm{C}_{15} \mathrm{H}_{24} \mathrm{NO}\left(\mathrm{M}^{+}+1\right)$ : 234.1858, found 234.1891. Compound 3b: (59 mg, 29\%). ${ }^{1} \mathrm{H}-\mathrm{NMR}(400 \mathrm{MHz}$, $\left.\mathrm{CDCl}_{3}\right): \delta 0.89,(\mathrm{~s}, 3 \mathrm{H}), 0.99(\mathrm{~s}, 3 \mathrm{H}), 1.04(\mathrm{~m}, 3 \mathrm{H}), 1.6(\mathrm{bs}, 2 \mathrm{H}), 1.65(\mathrm{ddt}, J=12.8,4,2 \mathrm{~Hz}, 1 \mathrm{H}), 1.70$ (ddt, $J=12.8,4,2 \mathrm{~Hz}, 1 \mathrm{H}), 2.29$ (dddd, $J=11.6,4,2 \mathrm{~Hz}, 1 \mathrm{H}), 2.76$ (tt, $J=11.2,4 \mathrm{~Hz}, 1 \mathrm{H}), 3.79$ (m, $1 \mathrm{H}), 3.8(\mathrm{~d}, J=12.8 \mathrm{~Hz}, 1 \mathrm{H}), 3.84(\mathrm{~d}, J=12.8 \mathrm{~Hz}, 1 \mathrm{H}), 7.3(\mathrm{~m}, 5 \mathrm{H}) .{ }^{13} \mathrm{C}-\mathrm{NMR}\left(100 \mathrm{MHz}, \mathrm{CDCl}_{3}\right): \delta$

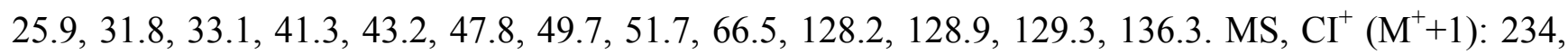
216, 174, 162, 108, 106, 91. HRMS calcd. for $\mathrm{C}_{15} \mathrm{H}_{24} \mathrm{NO}\left(\mathrm{M}^{+}+1\right)$ : 234.1858, found 234.1852.

5,5-Dimethyl-3-[(S)- $\alpha$-methylbenzylamino]cyclohexanol (cis-4 and trans-4). Compound cis-4: (352 mg, $69 \%),[\alpha]_{\mathrm{D}}=-48\left(c=3.26, \mathrm{CHCl}_{3}\right) . \mathrm{IR}\left(\mathrm{KBr}, \mathrm{cm}^{-1}\right): 3439,3257,3028,1646 .{ }^{1} \mathrm{H}-\mathrm{NMR}(400 \mathrm{MHz}$, $\left.\mathrm{CDCl}_{3}\right): \delta 0.70(\mathrm{~s}, 3 \mathrm{H}), 0.97(\mathrm{~s}, 3 \mathrm{H}), 0.97(\mathrm{t}, J=11.8 \mathrm{~Hz}, 1 \mathrm{H}), 0.97(\mathrm{t}, J=12 \mathrm{~Hz}, 1 \mathrm{H}), 1.07$ (q, $J=11.6 \mathrm{~Hz}$, $1 \mathrm{H}), 1.42(\mathrm{~d}, J=6.4 \mathrm{~Hz}, 3 \mathrm{H}), 1.63(\mathrm{ddt}, J=12.4,4.2 \mathrm{~Hz}, 1 \mathrm{H}), 1,70(\mathrm{ddt}, J=12.8,3.6,2.0 \mathrm{~Hz}, 1 \mathrm{H})$, $2.13\left(\mathrm{~m}, J_{\text {gem }}=11.6 \mathrm{~Hz}, 1 \mathrm{H}\right), 2.37(\mathrm{bs}, 2 \mathrm{H}), 2.53(\mathrm{tt}, J=11.6,4.0 \mathrm{~Hz}, 1 \mathrm{H}), 3.65(\mathrm{tt}, J=11.2,4.8 \mathrm{~Hz}$, $1 \mathrm{H}), 4.00$ (q, $J=6.4 \mathrm{~Hz}, 1 \mathrm{H}), 7.30-7.38(\mathrm{~m}, 5 \mathrm{H}) .{ }^{13} \mathrm{C}-\mathrm{NMR}\left(100 \mathrm{MHz}, \mathrm{CDCl}_{3}\right): \delta 24.3,26.0,31.8$, 33.3, 43.3, 44.7, 48.1, 49.5, 55.1, 66.8, 126.8, 127.3, 128.7, 144.3. $\mathrm{MS} \mathrm{CI}^{+}\left(\mathrm{M}^{+}+1\right): 248,247,232,230$, 176, 105. HRMS $\mathrm{CI}^{+}$calcd. for $\mathrm{C}_{16} \mathrm{H}_{26} \mathrm{NO}\left(\mathrm{M}^{+}+1\right)$ : 248.2014, found 248.2132. Compound trans-4: $(32 \mathrm{mg}, 6 \%)[\alpha]_{\mathrm{D}}=-28\left(c=0.24, \mathrm{CHCl}_{3}\right)$. IR $\left(\mathrm{KBr}, \mathrm{cm}^{-1}\right): 3,376,3,067,3,029,1,633 .{ }^{1} \mathrm{H}-\mathrm{NMR}$ $\left(400 \mathrm{MHz}, \mathrm{CDCl}_{3}\right): \delta 0.75(\mathrm{~s}, 3 \mathrm{H}), 0.93(\mathrm{~s}, 3 \mathrm{H}), 0.94(\mathrm{bq}, J=10.2 \mathrm{~Hz}, 1 \mathrm{H}), 0.99(\mathrm{t}, J=12 \mathrm{~Hz}, 1 \mathrm{H})$, $1.04(\mathrm{bq}, J=12 \mathrm{~Hz}, 1 \mathrm{H}), 1.40(\mathrm{~d}, J=6.8 \mathrm{~Hz}, 3 \mathrm{H}), 1.50(\mathrm{~m}, 1 \mathrm{H}), 1.63$ (ddt, $J=12.4,4.2 \mathrm{~Hz}, 1 \mathrm{H}), 2.01$ (bs, 2H), 2.35 (dddd, $J=11.6,5.6,4.2 \mathrm{~Hz}, 1 \mathrm{H}), 2.59$ (tt, $J=11.6,4.1 \mathrm{~Hz}, 1 \mathrm{H}), 3.64$ (tt, $J=10.8,4.4 \mathrm{~Hz}$, $1 \mathrm{H}), 4.03(\mathrm{q}, J=6.8 \mathrm{~Hz}, 1 \mathrm{H}), 7.32-7.35(\mathrm{~m}, 5 \mathrm{H}) .{ }^{13} \mathrm{C}-\mathrm{NMR}\left(50 \mathrm{MHz}, \mathrm{CDCl}_{3}\right): \delta 24.9,26.2,31.7,33.2$, 
42.6, 46.5, 48.4, 49.3, 54.8, 67.1, 126.7, 127.1, 128.7, 145.4. $\mathrm{MS} \mathrm{CI}^{+}\left(\mathrm{M}^{+}+1\right): 248,247,232,230,176$, 105. HRMS CI ${ }^{+}$calcd. for $\mathrm{C}_{16} \mathrm{H}_{25} \mathrm{NO}\left(\mathrm{M}^{+}+1\right)$ : 248.2014, found 248.2341.

\section{Conclusions}

In conclusion, 1,3-amino alcohols $\mathbf{3}$ and $\mathbf{4}$ were obtained as diastereoisomeric mixtures in good yield by reduction of the corresponding $\beta$-enaminoketones $\mathbf{1}$ and $\mathbf{2}$, which were analyzed by gas chromatography/mass spectrometry using a chiral column. Two diastereomeric pairs were identified for compound $\mathbf{3}$ and two diasteromeric pairs, cis-4 and trans $\mathbf{4}$, for compound $\mathbf{4}$. Chromatographic techniques allowed the separation of cis-4 and trans $\mathbf{- 4}$. On the other hand, NMR NOESY experiments enabled us to establish a chair conformation and a syn-orientation of the hydroxyl and amino groups for cis-4 and a boat conformation with anti-orientation of the hydroxyl and amino groups for trans-4.

\section{Acknowledgements}

We are grateful to María Gregoria Medina Pintor for her technical support and PROMEP-SEP for economic support for this publication.

\section{References and Notes}

1. Shibahara, S.; Kondo, S.; Maeda, K.; Umezawa, H.; Ohno, M. Total synthesis of negamycin and the antipode. J. Am. Chem. Soc. 1972, 94, 4353-4354.

2. Kozikowski, A.P.; Chen, Y.-Y. Intramolecular nitrile oxide cycloaddition (INOC) reactions in the indole series. 2. Total synthesis of racemic and optically active paliclavine and 5-epi-paliclavine. J. Org. Chem. 1981, 46, 5248-5250.

3. Wang, Y.-F.; Izawa, T.; Kobayashi, S.; Ohno, M. Stereocontrolled synthesis of (+)-negamycin from an acyclic homoallylamine by 1,3-asymmetric induction. J. Am. Chem. Soc. 1982, 104, 6465-6466.

4. Hashiguchi, S.; Kawada, A.; Natsugari, H. Stereoselective synthesis of sperabillins and related compounds. J. Chem. Soc. Perkin Trans. 1 1991, 2435-2444.

5. Knapp, S. Synthesis of complex nucleoside antibiotics. Chem. Rev. 1995, 95, 1859-1876.

6. Sakai, R.; Kamiya, H.; Murata, M.; Shimamoto, K. Dysiherbaine: A new neurotoxic amino acid from the micronesian marine sponge Dysidea herbacea. J. Am. Chem. Soc. 1997, 119, 4112-4116.

7. Kempf, D.J.; Marsh, K.C.; Denissen, J.F.; McDonald, E.; Vasavanonda, S.; Flentge, C.A.; Green, B.E.; Fino, L.; Park, C.H.; Kong, X.-P.; et al. ABT-538 is a potent inhibitor of human immunodeficiency virus protease and has high oral bioavailability in humans. Proc. Natl. Acad. Sci. USA 1995, 92, 2484.

8. Sham, H.L.; Zhao, C.; Li, L.; Betebenner, D.A.; Saldivar, A.; Vasavanonda, S.; Kempf, D.J.; Plattner, J.J.; Norbeck, D.W. Novel lopinavir analogues incorporating non-aromatic P-1 side chains-synthesis and structure-activity relationships. Bioorg. Med. Chem. Lett. 2002, 12, 3101-3103.

9. Haight, A.R.; Stuk, T.L.; Allen, M.S.; Bhagavatula, L.; Fitzgerald, M.; Hannick, S.M.; Kerdesky, F.A.J.; Menzia, J.A.; Parekh, S.I.; Robbins, T.A.; et al. Reduction of an enaminone: Synthesis of the diamino alcohol core of ritonavir. Org. Process Res. Dev. 1999, 3, 94-100. 
10. Shi, Z.; Harrison, B.A.; Verdine, G.L. Unpredictable stereochemical preferences for Mu opioid receptor activity in an exhaustively stereodiversified library of 1,4-enediols. Org. Lett. 2003, 5, 633-636.

11. Kondo, S.; Shibahara, S.; Takahashi, S.; Maeda, K.; Umezawa, H.; Ohno, M. Negamycin, a novel hydrazide antibiotic. J. Am. Chem. Soc. 1971, 93, 6305-6306.

12. Raju, B.; Mortell, K.; Anandan, S.; O’Dowd, H.; Gao, H.; Gomez, M.; Hackbarth, C.; Wu, C.; Wang, W.; Yuan, Z.; et al. N- and C-terminal modifications of negamycin. Bioorg. Med. Chem. Lett. 2003, 13, 2413-2418.

13. Naidu, S.V.; Kumar, P.A. Simple and efficient approach to 1,3-aminoalcohols: Application to the synthesis of (+)-negamicyn. Tetrahedron Lett. 2007, 48, 3793-3796.

14. Carlier, P.R.; Lo, M.M.-C.; Lo, P.C.-K.; Richelson, E.; Tatsumi, M.; Reynolds, I.J.; Sharma, T.A. Synthesis of a potent wide-spectrum serotonin-, norepinephrine-, dopamine-reuptake inhibitor (SNDRI) and a species-selective dopamine-reuptake inhibitor based on the gamma-amino alcohol functional group. Bioorg. Med. Chem. Lett. 1998, 8, 487-492.

15. Wang, X.-B.; Kodama, K.; Hirose, T.; Yang, X.-F.; Zhang, G.-Y. Chirality control in the enantioselective arylation of aromatic aldehydes catalized by cis- $(1 R, 2 S)$-2-benzamidocyclohexanecarboxylic acid derived 1,3-aminoalcohols. Tetrahedron: Asymmetry 2010, 21, 75-80.

16. Geng, H.; Zhang, W.; Chen, J.; Hou, G.; Zhou, L.; Zou, Y.; Wu, W.; Zhang, X. Rhodiumcatalized enantioselective and diastereoselective hydrogenation of $\beta$-ketoenamides: Efficient access to anti-1,3-amino alcohols. Angew. Chem. Int. Ed. 2009, 48, 6052-6054.

17. Davis, F.A.; Gaspari, P.M.; Nolt, B.M.; Xu, P. Asymmetric synthesis of acyclic 1,3-amino alcohols by reduction of $N$-sulfinyl $\beta$-amino ketones. Formal synthesis of (-)-pinidol and (+)-epipinidol. J. Org. Chem. 2008, 73, 9619-9626.

18. Menche, D.; Arikan, F.; Li, J.; Rudolph, S. Directed reductive amination $\beta$-hydroxy-ketones: Convergent assembly of the ritonavir/lopinavir core. Org. Lett. 2007, 9, 267-270.

19. Kochi, T.; Tang, T.P.; Ellman, J.A. Asymmetric synthesis of syn- and anti-1,3-amino alcohols. J. Am. Chem. Soc. 2002, 124, 6518-6519.

20. Keck, G.E.; Truong, A.P. Directed reduction of $\beta$-amino ketones to syn- or anti-1,3-amino alcohol derivatives. Org. Lett. 2002, 4, 3131-3134.

21. Vilaplana, M.J.; Molina, P.; Arques, A.; Andrés, C.; Pedrosa, R. Synthesis of the novel chiral 1,3-amino alcohol 8- $N, N$-bis(Ferrocenylmethyl)amino-menthol and its use as catalyst in the enantioselective addition of diethylzinc to aldehydes. Tetrahedron: Asymmetry 2002, 13, 5-8.

22. Panev, S.; Linden, A.; Dimitrov, V. Chiral aminoalcohols with a menthane skeleton as catalyst for the enantioselective addition of diethylzinc to benzaldehyde. Tetrahedron: Asymmetry 2001, 12, 1313-1321.

23. Andrés, C.; Duque-Soladana, J.P.; Iglesias, J.M.; Pedrosa, R. Diastereoselective 5-exo-trig radical cyclisation on $\mathrm{N}$-acryloyl-tetrahydro-1,3-oxazines. A novel approach to enantiopure 3 -substituted pyrrolidines. Tetrahedron Lett. 1996, 37, 9085-9086.

24. Liu, D.; Gao, W.; Wang, C.; Zhang, X. Practical synthesis of practical enantiopure $\gamma$-aminoalcohols by rhodium-catalyzed asymmetric hydrogenation of $\beta$-secondary-amino ketones. Angew. Chem. Int. Ed. 2005, 44, 1687-1689. 
25. Rice, G.T.; White, M.C. Allylic C-H amination for the preparation of syn-1,3-amino alcohol motifs. J. Am. Chem. Soc. 2009, 131, 11707-11711.

26. Millet, R.; Träff, A.M.; Petrus, M.L.; Bäckvall, J.-E. Enantioselective synthesis of syn and anti-1,3-aminoalcohols via $\beta$-aminoketones and subsequent reduction/dynamic kinetic asymmetric transformation. J. Am. Chem. Soc. 2010, 132, 15182-15184.

27. Solé, C.; Whiting, A.; Gulyás, H.; Fernández, E. Highly enantio and diastereoselective synthesis of $\gamma$-amino alcohols from $\alpha, \beta$-unsaturated imines trough a one-pot $\beta$-boration/reduction/oxidation sequence. Adv. Synth. Catal. 2011, 353, 376-384.

28. Anzai, M.; Yanada, R.; Fujii, N.; Ohno, H.; Ibuka, T.; Takemoto, Y. Asymmetric synthesis of $\beta^{2,3}$-amino acids by $\operatorname{InI}-\mathrm{Pd}(0)$-promoted metalation and addition of chiral 2-vinylaziridines. Tetrahedron 2002, 58, 5231-5239.

29. Raghavan, S.; Rajender, A. Stereoselective synthesis of (-)-allosedamine and (1R,3R)-HPA-12 from $\beta$ - $p$-toluenesulfonamido- $\gamma, \delta$-unsaturated sulfoxide. Tetrahedron 2004, 60, 5059-5067.

30. Patti, A.; Pedotti, S. Chemoenzymatic access to all four enantiopure stereoisomers of 1-ferrocenyl-1,3-butanediol. Tetrahedron: Asymmetry 2006, 17, 778-785.

31. Barbarotto, M.; Geist, J.; Choppin, S.; Colobert, F. SmI 2 -coupling reaction of chiral non-racemic $\alpha$-bromo- $\alpha$-sulfinyl ketones with imines: Synthesis of enantiomerically pure 2-methyl-3-amino-1ol moieties. Tetrahedron: Asymmetry 2009, 20, 2780-2787.

32. Olsson, C.; Helgesson S.; Frejd, T. New bicyclic $\gamma$ - and $\delta$-aminoalcohols as catalyst for the asymmetric diethylzinc addition to benzaldehyde. Tetrahedron: Asymmetry 2008, 19, 1484-1493.

33. Levy, L.M.; de Gonzalo, G.; Gotor, V. Resolution of $N$-protected cis- and trans-3-aminocyclohexanols via lipase-catalyzed enantioselective acylation in organic media. Tetrahedron: Asymmetry 2004, 15, 2051-2056.

34. Bernardelli, P.; Bladon, M.; Lorthiois, E.; Manage, A.C.; Vergne, F.; Wrigglesworth, R. Resolution of trans-3-aminocyclohexanol. Tetrahedron: Asymmetry 2004, 15, 1451-1455.

35. Santos, E.; Padilla, J.; Crabbé, P. Optical properties dimedonyl derivatives of $\alpha$-phenylethylamine. Can. J. Chem. 1967, 45, 2275-2277.

36. Dudek, G.O.; Holm, R.H. Nuclear magnetic resonance studies of keto-enol equilibria. III. $\alpha, \beta$-unsaturated- $\beta$-ketoamines. J. Am. Chem. Soc. 1962, 84, 2691-2696.

37. Crystal data for $\mathrm{C}_{16} \mathrm{H}_{21} \mathrm{NO}(2), M_{\mathrm{r}}=243.34 \mathrm{gmol}^{-1}, 0.41 \times 0.34 \times 0.16 \mathrm{~mm}^{3}$, monoclinic, space group P2(1), $\mathrm{a}=9.6513(16), \mathrm{b}=7.0546(11), \mathrm{c}=21.462(4) \AA, \alpha=90, \beta=93.259(3), \gamma=90^{\circ}$, $\mathrm{V}=1458.9(4) \AA^{3}, \mathrm{Z}=4, \rho_{\text {calcd }}=1.108 \mathrm{gcm}^{-3}, \theta_{\max }=25^{\circ}, 5149$ independent reflections, $\mathrm{R}_{1}=0.0700$ for 14134 reflections with $\mathrm{I}>2 \sigma(\mathrm{I})$ and $\mathrm{wR}_{2}=0.1455$ for all data, 2 parameters. Crystallographic data for the structure reported in this paper have been deposited with the Cambridge Crystallographic Data Centre as supplementary publication no. CCDC 841749.

38. Bartoli, G.; Cimarelli, C.; Palmieri, G. Convenient procedure for the reduction of $\beta$-enamino ketones: Synthesis of $\gamma$-amino alcohols and tetrahydro-1,3-oxazines. J. Chem. Soc. Perkin Trans. 1 1994, 537-543.

39. San Martin, R.; Martínez de Marigorta, E.; Domínguez, E. A convenient alternative route to $\beta$-aminoketones. Tetrahedron 1994, 50, 2255-2264. 
40. Bartoli, G.; Cupone, G.; Dal Pozzo, R.; de Nino, A.; Mariuolo, L.; Procopio, A.; Tagarelli, A. Stereoselective reduction of enaminones to syn- $\gamma$-aminoalcohols. Tetrahedron Lett. 2002, 43, 7441-7444.

41. Machado, M.A.; Harris, M.I.N.C.; Braga, A.C.H. Studies on the reduction of $\beta$-enamino ketones. J. Braz. Chem. 2006, 17, 1440-1442.

42. Cimarelli, C.; Giuli, S.; Palmieri, G. Stereoselective synthesis of enantiopure $\gamma$-aminoalcohols by reduction of chiral $\beta$-enaminoketones. Tetrahedron: Asymmetry 2006, 17, 1308-1317.

43. Cimarelli, C.; Palmieri, G.; Volpini, E. Regio- and stereoselective double alkylation of $\beta$-enamino esters with organolitium reagents followed by one-pot reduction: Convenient method for the synthesis of tertiary $\gamma$-amino alcohols. Tetrahedron 2006, 62, 9423-9432.

44. Elassar, A.-Z.A.; El-Khair, A.A. Recent developments in the chemistry of enaminones. Tetrahedron 2003, 59, 8463-8480.

45. Bartoli, G.; Cimarelli, C.; Marcantoni, E.; Palmieri, G.; Petrini, M. Chemo- and diastereoselective reduction of beta-enamino esters: A convenient synthesis of both cis- and trans- $\gamma$-amino alcohols and $\beta$-amino esters. J. Org. Chem. 1994, 59, 5328-5335.

Sample Availability: Not available.

(C) 2012 by the authors; licensee MDPI, Basel, Switzerland. This article is an open access article distributed under the terms and conditions of the Creative Commons Attribution license (http://creativecommons.org/licenses/by/3.0/). 